\title{
THE PREDICTIVE VALUE OF ULTRASONOGRAPHY FOR POTENTIALLY MALIGNANT THYROID NODULES
}

\author{
POTANSIYEL MALIGN TIROID NODÜLLERI IÇIN ULTRASONOGRAFININ TAHMIN \\ DEĞERI
}

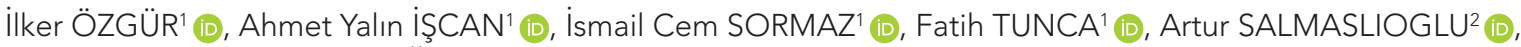 \\ Aysel BAYRAM ${ }^{3}$ (D), Gülçin YEĞEN³ (D), Yasemin Giles ŞENYÜREK (D)
}

Istanbul University, Istanbul Faculty of Medicine, 'Department of General Surgery, ${ }^{2}$ Department of Radiology, ${ }^{3}$ Department of Pathology, Istanbul, Turkey

ORCID IDs of the authors: I.Ö. 0000-0003-1499-0503; A.Y.i. 0000-0002-5576-9496; I.C.S. 0000-0001-6907-978X; F.T. 0000-0001-6889-3894; A.S. 0000-0002-8576-7942; A.B. 0000-0002-5014-0074; G.Y. 0000-0003-2497-219X; Y.G.Ş. 0000-0001-5339-1840

Cite this article as: Ozgur I, Iscan AY, Sormaz IC, Tunca F, Salmaslioglu A, Bayram A, et al. The predictive value of ultrasonography for potentially malignant thyroid nodules. J Ist Faculty Med 2020;83(4):378-83. doi: 10.26650/IUITFD.2020.0079

\begin{abstract}
Objective: In this study, we aimed to predict the malignancy potential of a thyroid nodule based on ultrasonography (US) features.

Material and Method: The data of 726 nodules in 619 patients who underwent thyroidectomy between 2005 and 2012 at Istanbul University, Istanbul Medical Faculty were retrospectively analyzed. US features of nodules were recorded and matched with pathology reports and each US feature was evaluated for diagnostic value.

Results: The study group consisted of mainly female patients $(86.9 \%)$ and the mean age was 46,3 years. Thyroid cancer was detected in 374 (51.7\%) nodules and the most common type was papillary thyroid cancer $97 \%(n=341)$. Microcalcifications $(p=0.0001)$, irregular margin $(p=0.001)$ and hypoechogenicity $(p=0.038)$ were correlated with malignancy. The absence of any of these suspicious US features significantly predicted benign disease $(p=0.0001)$. An increasing number of suspicious features predicted malign disease with increasing specificity, positive predictive value, and likelihood ratio. Microcalcifications and irregular borders had high specificity (>80\%) to predict thyroid cancer.

Conclusion: The presence of microcalcifications, irregular margin, and hypoechogenicity in a thyroid nodule significantly correlates with malignant disease. Microcalcifications and irregular borders had high specificity to predict thyroid cancer. The probability of thyroid cancer increases with an increasing number of suspicious US features.
\end{abstract}

Keywords: Thyroid nodules, ultrasonography, thyroid cancer

\section{ÖZET}

Amaç: Bu çalışmada tiroid nodüllerindeki malignite olasılığını ultrasonografi (US) özelliklerinin öngörme seviyesini araştırmayı amaçladık.

Gereç ve Yöntem: İstanbul Üniversitesi İstanbul Tıp Fakültesi'nde, 2005 ila 2012 yılları arasında total tiroidektomi ameliyatı olan 619 hastada 726 nodül geriye dönük olarak incelendi. Tiroid nodüllerinin US özellikleri kaydedildi, patoloji raporları ile karşılaştırılarak eşleştirildi ve US özelliklerin tanısal değeri hesaplandı.

Bulgular: Çalışmaya alınan hastalarda kadın oranı $(\% 86,9)$ olup, ortalama yaş 46,3 olarak hesaplandı. Tiroid kanseri $374(\% 51,7)$ nodülde tespit edilirken, en sık kanser türü \%97 ( $n=341)$ oranla papiller tiroid kanseriydi. Tiroid nodülünde mikrokalsifikasyon $(p=0,0001)$, düzensiz sınır $(p=0,001)$ ve hipoekojenite $(p=0,038)$ varlığı malignite ile korelasyon gösterdi. Mikrokalsifikasyon ve düzensiz sınır özelliklerinin kanser öngörüsü bakımından özgüllüğü yüksek (>\%80) bulundu. Nodülde bu şüpheli US özelliklerinden hiçbirinin olmaması selim hastalığı $(p=0,0001)$ tahmin etti. Artan US şüpheli özelliklerin sayısı, artan özgüllük, pozitif prediktif değer ve olasılık oranı ile malign hastalığı öngördü. Mikro kalsifikasyonlar ve düzensiz sınır tiroid kanserini öngörmek için yüksek özgüllüğe (>\%80) sahipti.

Sonuç: Bir tiroid nodülünde mikrokalsifikasyon, düzensiz sınır ve hipoekojenite varlığında tiroid kanseri olasılığı anlamlı şekilde yüksektir. Malignite öngörüsü açısından özgüllüğü en yüksek bulgular mikrokalsifikasyon ve düzensiz sınırdır. Bir nodüldeki şüpheli US özelliklerinin sayısı arttıkça malignite olasıı̆̆ı da paralel olarak anlamlı şekilde artar.

Anahtar Kelimeler: Tiroid nodülleri, ultrasonografi, tiroid kanseri

Corresponding author/iletişim kurulacak yazar: dr.ilkerozgur@gmail.com

Submitted/Başvuru: 20.06.2020 • Accepted/Kabul: 21.07.2020 • Published Online/Online Yayın: 19.10.2020

(C) Telif Hakkı $2020 \mathrm{~J}$ Ist Faculty Med - Makale metnine jmed.istanbul.edu.tr web sayfasından ulaşılabilir.

(C) Copyright 2020 by J Ist Faculty Med - Available online at jmed.istanbul.edu.tr 


\section{INTRODUCTION}

The prevalence of thyroid nodules in the general population ranges between 3 to $7 \%$ for palpable nodules and up to 50 to $67 \%$ for those detected by ultrasonography (US) (1). The increasing detection rate of thyroid nodules with the use of high-resolution US has necessitated a careful diagnostic approach to identify nodules with malignant potential. Fine needle aspiration biopsy (FNAB) is the primary diagnostic modality for patients with a thyroid nodule and with its utility, unnecessary surgery rates decreased. The US is also used to determine whether nodules have an increased risk for malignancy. Several sonographic features are associated with an increased risk of thyroid cancer, including hypoechogenicity, microcalcifications, irregular margin, intranodular hypervascularity, and taller rather than wider shape $(2,3)$. FNAB performed under US guidance improves the diagnostic accuracy of the procedure (4). FNAB is reported to have high sensitivity (68-98 \%) and varying specificity (54-90\%) (5-7). Nevertheless, false negative (FN) FNAB cytology results are possible $(8,9)$ due to the likelihood of having an $\mathrm{FN}$ result with nodules $\geq 4 \mathrm{~cm}(10,11)$, cystic lesions (12), follicular neoplasms (13), or a follicular variant of papillary thyroid carcinoma (PTC) (14). There is also interobserver variation in the interpretation of some sonographic features, such as microcalcifications, in thyroid US examination (15). New sonographic reporting systems were suggested to stratify the malignancy risk of thyroid nodules according to the certain sonographic features and to facilitate communication among the clinicians (16). This study aimed to determine the US features that were correlated with malignant nodules and to investigate the diagnostic value of these sonographic features to predict malignancy.

\section{MATERIAL AND METHOD}

The records of the patients who underwent thyroid surgery from January 2007 to May 2012 at the Department of General Surgery, Istanbul Medical Faculty were retrospectively analyzed. Six-hundred and nineteen patients who had accessible full clinical data and sonography images and/or reports were included. In these 619 patients, 726 index thyroid nodules were evaluated by thyroid ultrasonography (US). Of 619 patients, 494 (80\%) had at least two nodules and $125(20 \%)$ solitary thyroid nodule. All patients were evaluated with thyroid function tests. Patients who had depressed levels of serum thyroid-stimulating hormone (TSH) underwent thyroid scintigraphy. Neck US was done in all patients preoperatively by using 13-5 MHz linear array transducer (Sonoline Antares, Siemens, Erlangen, Germany). The US was performed by a single radiologist experienced in thyroid imaging. Nodules were described for size, echographic structure (solid vs cystic), echogenicity (hyper-, hypo-), calcification (micro-, macro-, eggshell or absence), and margin (cir- cumscribed or irregular/lobulated) from US reports and/ or images. Taller-than-wider feature was not reported in all of the US reports, and this feature was not included for statistical analysis.

\section{Analysis of US findings}

Sonographic and final histopathological findings were correlated in all of the 726 nodules. The records of US findings of index nodules were correlated with the macroscopic and microscopic description of thyroidectomy specimens in the histopathological reports to assess accurate nodule matching. Individual sonographic features that were significantly associated with thyroid cancer at the final histopathological examination were determined as the US features suspicious of thyroid cancer. The diagnostic value of the US to predict thyroid cancer was evaluated according to the presence of single or more suspicious sonographic findings in a thyroid nodule. The presence of single or more suspicious sonographic findings in a nodule was defined as true positive (TP) or false positive (FP) US result in case the nodule proved to be malignant or benign, respectively. The absence of suspicious sonographic findings in a nodule was defined as true negative (TN) or false negative (FN) US result in case the nodule proved to be benign or malignant, respectively. The sensitivity (TP/(TP+FN), specificity (TN/ $(\mathrm{TN}+\mathrm{FP})$, positive predictive value (TP/(TP+FP), and negative predictive value (TN/(TN+FN) of suspicious US findings for preoperative diagnosis of thyroid cancer were determined.

Statistical evaluation was performed with SPSS Windows Ver. 21.0. The chi-square test was used to determine the differences in the frequency of thyroid cancer in different US features groups. Student's T-test was used to compare the continuous data between the groups. The significance level was set as $p<0.05$.

\section{RESULTS}

Of 619 patients, 538 (86.9\%) were female and 81 (13.1\%) were male with a mean age of 46.3 years. The final histopathological examination revealed thyroid cancer in 374 (51.7\%) of 726 nodules. The frequency of papillary thyroid cancer was $97 \%(n=341)$, Hurthle cell cancer $1.5 \%(n=3)$, follicular cancer $1 \%(n=2)$ and medullary cancer $0.5 \%$ $(n=1)$ in all patients. The mean tumor size was $23.6 \pm 12.8$ $\mathrm{mm}$. The diameters of nodules measured by the US ranged from 12 to $80 \mathrm{~mm}$ with a mean of $25.3 \pm 11.4 \mathrm{~mm}$. There was no statistical significance in nodule size between malignant and benign nodules $(19.6 \pm 16 \mathrm{~mm}$ vs. $18.9 \pm 14 \mathrm{~mm}, \mathrm{p}>0.05)$.

\section{Correlation of US features with final histopathology}

Of 726 nodules, 365 (50.3\%) were solid and 361 (49.7\%) had solid-cystic mixed structure. The majority $(n=477$, $65.7 \%$ ) of the nodules was hypoechoic. The frequency of 
irregular/lobulated margin, macrocalcifications and microcalcifications was $22.2 \%(n=161), 27.1 \%(n=197)$, and $21.3 \%(n=155)$, respectively. Seven $(0.9 \%)$ nodules had egg-shell calcification $0.9 \%$. The final histopathological examination revealed thyroid cancer in 374 (51.5\%) of 726 nodules. The rate of malignancy in solid and solid-cystic mixed nodules showed no significant difference (Table 1). Hypoechogenicity, microcalcifications, and irregular/lobulated margin of a nodule were found to be significantly correlated with thyroid cancer (Table 1). These three US features were defined as suspicious for malignancy. The rate of malignancy in hypoechoic nodules and nodules with microcalcifications and irregular/lobulated border was $54.3 \%, 63.2 \%$, and $71.4 \%$, respectively.

The sensitivity, specificity, PPV, and NPV of suspicious sonographic criteria for preoperative diagnosis of thyroid cancer were shown in Table 2. Hypoechogenicity had the highest sensitivity (69\%) but the lowest specificity (38\%). The presence of microcalcifications and irregular/lobulated had both high specificity ( $84 \%$ and $87 \%$, respectively) but low sensitivity for preoperative diagnosis of thyroid cancer.

Of 726 nodules, 160 (22\%) had no suspicious sonographic features, whereas one, two, or three suspicious sonographic features were present in 374 (51.5\%), 164 (22.6\%), and $28(3.9 \%)$ nodules, respectively. The absence of suspicious sonographic findings was significantly associated with benign nodule with a likelihood ratio of 22.6 (Table 3). The negative predictive value of US in nodules with no suspicious features was $65 \%$.

The presence of one suspicious feature in a nodule was not associated with increased frequency of malignancy, whereas the presence of two or three suspicious features

Table 1: Correlation of final histopathological diagnosis and US feature groups.

\begin{tabular}{lccc}
\hline & \multicolumn{2}{c}{ Final histopathology of nodules } & \\
US features & Malignant $(\mathbf{n = 3 7 4 )}$ & Benign ( $\mathbf{n = 3 5 2 )}$ & $\mathbf{p}$ \\
Hypoechogenity & $\mathbf{n}(\%)$ & $\mathbf{n}(\%)$ & \\
Solid nodule & $259(69.2)$ & $218(62)$ & 0.038 \\
Mixed structure & $197(53)$ & $168(48)$ & 0.2 \\
Macro calcifications & $177(47)$ & $184(52)$ & 0.1 \\
Micro calcifications & $92(24.6)$ & $105(30)$ & 0.1 \\
Irregular/lobulated margin & $98(26)$ & $57(16)$ & 0.001 \\
Egg shell calcifications & $115(30.7)$ & $46(13)$ & 0.0001 \\
\hline
\end{tabular}

Table 2: Binary classification of US findings.

\begin{tabular}{lcccc}
\hline US features & Sensitivity (\%) & Specificity (\%) & PPV (\%) & NPV (\%) \\
Hypoechogenity & 69 & 38 & 54 & 54 \\
Microcalcifications & 26 & 84 & 63 & 51 \\
Irregular/lobulated border & 31 & 87 & 71 & 54 \\
\hline
\end{tabular}

Table 3: Malignancy and number of suspicious features correlation.

\begin{tabular}{|c|c|c|c|c|}
\hline \multirow[b]{2}{*}{ Nodule US features } & \multicolumn{2}{|c|}{ Final histopathology of nodules } & \multirow[b]{2}{*}{$p$} & \multirow[b]{2}{*}{$\begin{array}{l}\text { Likelihood } \\
\text { ratio }\end{array}$} \\
\hline & $\begin{array}{c}\text { Malignant }(n=374) \\
n(\%)\end{array}$ & $\begin{array}{c}\text { Benign }(n=352) \\
n(\%)\end{array}$ & & \\
\hline No suspicious feature & $56(15)$ & $104(29.5)$ & 0.0001 & 22.6 \\
\hline One suspicious feature & $191(51)$ & $183(52)$ & 0.8 & 0.06 \\
\hline Two suspicious feature & $103(27.5)$ & $61(17.3)$ & 0.001 & 11 \\
\hline Three suspicious feature & $24(6.4)$ & $4(1.1)$ & 0.0001 & 15 \\
\hline
\end{tabular}


Table 4: Binary classification of an increasing number of suspicious US findings.

\begin{tabular}{lcccc}
\hline & Sensitivity (\%) & Specificity (\%) & PPV (\%) & NPV (\%) \\
One suspicious feature & 51 & 48 & 51 & 48 \\
Two suspicious feature & 27.5 & 82.6 & 62.8 & 51.7 \\
Three suspicious feature & 6.4 & 98.8 & 85.7 & 50 \\
\hline
\end{tabular}

was significantly associated with cancer with a likelihood ratio of 11 and 15, respectively (Table 3 ). The probability of malignancy in nodules with one, two, and three suspicious US features was $13.6 \%, 62.8 \%$, and $85.7 \%$, respectively.

The specificity and PPV of the US for preoperative diagnosis of thyroid cancer in case of the presence of two suspicious US features in a nodule were $82.6 \%$ and $62.8 \%$, respectively. The specificity and PPV increased to $98.8 \%$ and $85.7 \%$, respectively, if three suspicious US features were observed in the same nodule (Table 4).

\section{DISCUSSION}

In this study, we investigated the diagnostic value of thyroid US for preoperative prediction of malignancy in thyroid nodules. We found out that the presence of microcalcifications, an irregular/lobulated margin, and marked hypoechogenicity in a nodule were significantly associated with histopathological diagnosis of thyroid cancer, and microcalcifications and irregular/lobulated margin were the US features which were highly specific for thyroid cancer. The likelihood of thyroid cancer increased as the number of suspicious US features increased in an index nodule.

Thyroid nodules are encountered commonly in daily practice due to the increased detection rate with the use of high-resolution US. It is important to differentiate between malignant and benign nodules for further management of the patient. Uncomplicated benign nodules can be followed up whereas suspicion of malignancy in a nodule constitutes the main indication for surgery. Thyroid US is the most valuable imaging method to determine the morphological characteristics of thyroid nodules, and FNAB is the primary diagnostic tool to predict the malignant potential of nodules $(1,17)$. The patients with nodular goiter may have solitary or multiple nodules and the likelihood of thyroid cancer per patient is independent of the number of nodules (18). Frates et al. determined that a strategy to biopsy the largest nodule in thyroid with multiple nodules would miss $14 \%$ of patients with two nodules who had cancer and approximately $50 \%$ of patients with three or more nodules who had cancer (18). The authors suggested the use of sonographic characteristics to prioritize nodules for FNA based on their risk of cancer. Nodule size is not predictive for malignancy $(18,19)$. Thyroid US is recommended to stratify the risk of malignancy in thyroid nodules and decide whether
FNAB is indicated (1). Solid component, hypoechogenicity, microlobulated or irregular margins, microcalcifications, and taller-than-wide shape in a nodule were found to be significantly associated with thyroid cancer $(16,20)$. In a recent meta-analysis, the specificities of microcalcifications, irregular margins, and a taller than wide shape were found as $87.8 \%, 83.1 \%$, and $96.6 \%$, respectively (21).

The composition of a nodule is defined as cystic, solid, spongiform, predominantly cystic/solid. The incidence of malignancy was found significantly higher in solid and predominantly solid nodules compared to predominantly cystic nodules $(15,16,18,22)$. Pure cystic nodules have a very low risk of malignancy $(15,22)$. We found no significant difference in the incidence of thyroid cancer between solid and mixed nodules. A possible explanation for this result may be that the majority of the mixed nodules in our study were predominantly solid and there were no pure cystic nodules included in the study.

The echogenic structure of a nodule refers to the echogenic level of a non-calcified solid portion of the nodule relative to surrounding thyroid parenchyma. A nodule can be described as either entirely or predominantly hyper-, iso-, hypo- or very hypoechoic. The hypoechoic structure was found to have a stronger relationship with cancer compared to iso- or hyperechoic nodules $(16,22)$. However, the sensitivity and specificity of hypoechogenicity to predict malignancy are not high and reported to be about $62 \%$ (21). This finding is similar to our results. We found the sensitivity of hypoechogenicity $69 \%$, but the specificity was $38 \%$.

Calcifications of the thyroid gland are classified as microcalcifications, macrocalcifications, and peripheral rim calcifications so-called as eggshell calcifications. Macrocalcifications alone are not specific for malignancy (23). Macrocalcifications are usually part of the degenerative process and together with eggshell calcifications, they are rarely reported with thyroid carcinoma $(16,24)$. Although colloid crystals, fibrin debris, or microcystic areas may be observed as echogenic foci by the US mimicking microcalcification, these are benign features (23). True microcalcifications correspond to psammoma bodies and highly specific for malignancy $(1,2,16,23)$. In our study, we found the specificity of microcalcifications to predict malignancy $84 \%$ which was compatible with the reported rates in the literature (21). 
Irregular or lobulated margins were significantly associated with thyroid cancer compared to well-circumscribed nodules (16). Irregular margins are reported to have low sensitivity but high specificity to predict cancer $(1,25$, 26). Previous studies reported the ill-defined borders to be associated with malignancy $(18,25,26)$. The arising new technologies and better sonographic ability of ultrasound devices led to better discrimination of borders. The well-known condition of thyroiditis with benign hyperplastic nodules which are reported to have ill-defined margins is a common finding and is not associated with malignancy $(16,29)$. A taller-than-wide shape is highly specific for malignancy, and this feature was reported to have the highest specificity compared to other US features to predict malignancy (21).

Risk stratification of thyroid nodules according to the sonographic characteristics is crucial to select the nodules for FNAB. Appropriate reporting systems with standard definitions have been necessitated for better communication between clinicians. Several Thyroid Imaging Reporting and Data Systems (TIRADS) such as EU-TIRADS, ACR-TIRADS, Kwak-TIRADS, and ATA US scores were developed $(1,16,20,21,23,30)$. All of these reporting systems classify the nodules according to the presence and number of suspicious US features. The risk of malignancy increases as the score or number of suspicious features increases in all of these risk classification systems. ACR-TIRADS is a more complicated system that gives points for each sonographic feature and score and classifies the nodules according to the sum of these points. Numerous studies showed that the diagnostic performance of these reporting systems is similar. In our study, we found that the likelihood of thyroid cancer significantly increased in a nodule when the number of suspicious US features increased. In nodules with two and three suspicious US features, the probability of malignancy increased by about 6 and 8 folds compared to nodules with one suspicious feature. We found that the specificities of the presence of two and three suspicious the US feature in a nodule to predict malignancy was $82.6 \%$ and $98.8 \%$, respectively.

There are some limitations to our study. This is a retrospective study. Sonographic data were not collected prospectively. Although it is highly specific for malignancy, the taller-than-wider feature was not available in all sonography reports and it could not be included in statistical analysis. For the same reason, we were unable to classify the nodules and evaluate the malignancy rate according to recently defined reporting systems.

\section{CONCLUSION}

The suspicious US features in a thyroid nodule are microcalcification, hypoechogenicity, and irregular/ border. The presence of microcalcification or irregular border predicts malignancy with a specificity higher than $80 \%$. The prob- ability of malignancy in a thyroid nodule significantly increases with the number of suspicious US features.

Ethics Committee Approval: Ethics committee approval was not received due to the retrospective nature of the study.

Informed Consent: Informed consent was not received due to the retrospective nature of the study.

Peer Review: Externally peer-reviewed.

Author Contributions: Conception/Design of Study- i.Ö., Y.G.Ş., F.T.; Data Acquisition- I.Ö., A.Y.I., I.C.S., F.T., A.S., A.B., G.Y., Y.G.Ş..; Data Analysis/Interpretation- I.Ö., G.Y., Y.G.; Drafting Manuscript-I.Ö., A.Y.I., A.S., A.B., Y.G.Ş.; Critical Revision of Manuscript- - I.Ö., I.C.S., F.T., Y.G.Ş.; Final Approval and Accountability- I.Ö., A.Y.I., I.C.S., F.T., A.S., A.B., G.Y., Y.G.Ş..; Technical or Material Support- I.Ö., Y.G.; Supervision- Y.G., F.T.

Conflict of Interest: Authors declared no conflict of interest.

Financial Disclosure: Authors declared no financial support.

Etik Komite Onayı: Retrospektif çalışma olduğundan etik komite onayı alınmamıştır.

Bilgilendirilmiş Onam: Retrospektif bir çalışma olduğundan bilgilendirilmiş onam alınmamıştır

\section{Hakem Değerlendirmesi: Dış bağımsız.}

Yazar Katkıları: Çalışma Konsepti/Tasarım- I.Ö., Y.G.Ş., F.T.; Veri Toplama- I.Ö., A.Y.I., I.C.S., F.T., A.S., A.B., G.Y., Y.G.Ş.; Veri Analizi/Yorumlama- I.Ö., G.Y., Y.G.; Yazı Taslağı- I.Ö., A.Y.i., A.S., A.B., Y.G.Ş.; İçeriğin Eleştirel İncelemesi- i.Ö., I.C.S., F.T., Y.G.Ş.; Son Onay ve Sorumluluk- I.Ö., A.Y.I., I.C.S., F.T., A.S., A.B., G.Y., Y.G.S...; Malzeme ve Teknik Destek- I.Ö., Y.G.; Süpervizyon- Y.G., F.T.

Çıkar Çatışması: Yazarlar çıkar çatışması beyan etmemişlerdir.

Finansal Destek: Yazarlar finansal destek beyan etmemişlerdir.

\section{REFERENCES}

1. Haugen BR, Alexander EK, Bible KC, Doherty GM, Mandel SJ, Nikiforov YE, et. al. 2015 American Thyroid Association Management Guidelines for Adult Patients with Thyroid Nodules and Differentiated Thyroid Cancer: The American Thyroid Association Guidelines Task Force on Thyroid Nodules and Differentiated Thyroid Cancer. Thyroid 2016;26(1):1-133. [CrossRef]

2. Cappelli C, Castellano M, Pirola I, Cumetti D, Agosti B, Gandossi $E$, et. al. The predictive value of ultrasound findings in the management of thyroid nodules. QJM 2007;100(1):29-35. [CrossRef]

3. Hong YJ, Son EJ, Kim EK, Kwak JY, Hong SW, Chang HS. Positive predictive values of sonographic features of solid thyroid nodule. Clin Imaging 2010;34(2):127-33. [CrossRef]

4. Carmeci C, Jeffrey RB, McDougall IR, Nowels KW, Weigel RJ. Ultrasound-guided fine-needle aspiration biopsy of thyroid masses. Thyroid 1998;8(4):283-9. [CrossRef] 
5. Tee YY, Lowe AJ, Brand CA, Judson RT. Fine-needle aspiration may miss a third of all malignancy in palpable thyroid nodules: a comprehensive literature review. Ann Surg 2007;246(5):714-20. [CrossRef]

6. Peng $\mathrm{Y}$, Wang $\mathrm{HH}$. A meta-analysis of comparing fineneedle aspiration and frozen section for evaluating thyroid nodules. Diagn Cytopathol 2008;36(12):916-20. [CrossRef]

7. Oertel YC, Miyahara-Felipe L, Mendoza MG, Yu K. Value of repeated fine needle aspirations of the thyroid: an analysis of over ten thousand FNAs. Thyroid 2007;17(11):1061-6. [CrossRef]

8. Lewis CM, Chang KP, Pitman M, Faquin WC, Randolph GW. Thyroid fine-needle aspiration biopsy: variability in reporting. Thyroid 2009;19(7):717-23. [CrossRef]

9. Yeh MW, Demircan O, Ituarte P, Clark OH. False-negative fine-needle aspiration cytology results delay treatment and adversely affect outcome in patients with thyroid carcinoma. Thyroid 2004;14(3):207-15. [CrossRef]

10. Pinchot SN, Al-Wagih H, Schaefer S, Sippel R, Chen H. Accuracy of fine-needle aspiration biopsy for predicting neoplasm or carcinoma in thyroid nodules $4 \mathrm{~cm}$ or larger. Arch Surg 2009;144(7):649-55. [CrossRef]

11. Yoon JH, Kwak JY, Moon HJ, Kim MJ, Kim EK. The diagnostic accuracy of ultrasound-guided fine-needle aspiration biopsy and the sonographic differences between benign and malignant thyroid nodules $3 \mathrm{~cm}$ or larger. Thyroid 2011;21(9):993-1000. [CrossRef]

12. Nguyen GK, Lee MW, Ginsberg J, Wragg T, Bilodeau D. Fine-needle aspiration of the thyroid: an overview. Cytojournal 2005;2(1):12. [CrossRef]

13. Faquin WC. Diagnosis and reporting of follicular-patterned thyroid lesions by fine needle aspiration. Head Neck Pathol 2009;3(1):82-5. [CrossRef]

14. Kesmodel SB, Terhune KP, Canter RJ, Mandel SJ, LiVolsi VA, Baloch ZW, et. al. The diagnostic dilemma of follicular variant of papillary thyroid carcinoma. Surgery 2003;134(6):1005-12. [CrossRef]

15. Malhi H, Beland MD, Cen SY, Allgood E, Daley K, Martin $\mathrm{SE}$, et. al. Echogenic foci in thyroid nodules: significance of posterior acoustic artifacts. AJR Am J Roentgenol 2014;203(6):1310-6. [CrossRef]

16. Kwak JY, Han KH, Yoon JH, Moon HJ, Son EJ, Park SH, et. al. Thyroid imaging reporting and data system for US features of nodules: a step in establishing better stratification of cancer risk. Radiology 2011;260(3):892-9. [CrossRef]

17. Gharib H, Papini E, Paschke R, Duick DS, Valcavi R, Hegedüs $L$, et. al. AACE/AME/ETA Task Force on Thyroid Nodules. American Association of Clinical Endocrinologists, Associazione Medici Endocrinologi, and European Thyroid Association Medical guidelines for clinical practice for the diagnosis and management of thyroid nodules: executive summary of recommendations. Endocr Pract 2010;16(3):46875. [CrossRef]
18. Frates MC, Benson CB, Doubilet PM, Kunreuther E, Contreras M, Cibas ES, et. al. Prevalence and distribution of carcinoma in patients with solitary and multiple thyroid nodules on sonography. J Clin Endocrinol Metab 2006;91(9):3411-7. [CrossRef]

19. Nam-Goong IS, Kim HY, Gong G, Lee HK, Hong SJ, Kim $W B$, et. al. Ultrasonography-guided fine-needle aspiration of thyroid incidentaloma: correlation with pathological findings. Clin Endocrinol (Oxf) 2004;60(1):21-8. [CrossRef]

20. Tessler FN, Middleton WD, Grant EG, Hoang JK, Berland LL, Teefey SA, et. al. ACR Thyroid Imaging, Reporting and Data System (TI-RADS): White Paper of the ACR TI-RADS Committee. J Am Coll Radiol 2017;14(5):587-95. [CrossRef]

21. Remonti LR, Kramer CK, Leitão CB, Pinto LC, Gross JL. Thyroid ultrasound features and risk of carcinoma: a systematic review and meta-analysis of observational studies. Thyroid 2015;25(5):538-50. [CrossRef]

22. Frates MC, Benson CB, Charboneau JW, Cibas ES, Clark OH, Coleman BG, et. al. Society of Radiologists in Ultrasound. Management of thyroid nodules detected at US: Society of Radiologists in Ultrasound consensus conference statement. Radiology 2005;237(3):794-800. [CrossRef]

23. Russ G, Bonnema SJ, Erdogan MF, Durante C, Ngu R, Leenhardt L. European Thyroid Association Guidelines for Ultrasound Malignancy Risk Stratification of Thyroid Nodules in Adults: The EU-TIRADS. Eur Thyroid J 2017;6(5):225-37. [CrossRef]

24. Khoo ML, Asa SL, Witterick IJ, Freeman JL. Thyroid calcification and its association with thyroid carcinoma. Head Neck 2002;24(7):651-5. [CrossRef]

25. Kim HG, Moon HJ, Kwak JY, Kim EK. Diagnostic accuracy of the ultrasonographic features for subcentimeter thyroid nodules suggested by the revised American Thyroid Association guidelines. Thyroid 2013;23(12):1583-9. [CrossRef]

26. Papini E, Guglielmi R, Bianchini A, Crescenzi A, Taccogna $S$, Nardi F, et. al. Risk of malignancy in nonpalpable thyroid nodules: predictive value of ultrasound and color-Doppler features. J Clin Endocrinol Metab 2002;87(5):1941-6. [CrossRef]

27. Wienke JR, Chong WK, Fielding JR, Zou KH, Mittelstaedt CA. Sonographic features of benign thyroid nodules: interobserver reliability and overlap with malignancy. J Ultrasound Med 2003;22(10):1027-31. [CrossRef]

28. Park JY, Lee HJ, Jang HW, Kim HK, Yi JH, Lee W, et. al. A proposal for a thyroid imaging reporting and data system for ultrasound features of thyroid carcinoma. Thyroid 2009;19(11):1257-64. [CrossRef]

29. Hoang JK, Lee WK, Lee M, Johnson D, Farrell S. US Features of thyroid malignancy: pearls and pitfalls. Radiographics 2007;27(3):847-60. [CrossRef]

30. Horvath E, Majlis S, Rossi R, Franco C, Niedmann JP, Castro $A$, et. al. An ultrasonogram reporting system for thyroid nodules stratifying cancer risk for clinical management. J Clin Endocrinol Metab 2009;94(5):1748-51. [CrossRef] 